\title{
Los perplejos de Cynthia Rimsky
}

Santiago: Sangría Editora, 2009, 388 pp.

LARA HÜBNer GonZÁLEZ Pontificia Universidad Católica de Chile. Santiago, Chile lhubner@uc.cl

\begin{abstract}
Tos perplejos (2009) de Cynthia Rimsky es una novela que cualquier Leditor quisiera para inaugurar su proyecto editorial. Utilizo la palabra inaugurar porque, al margen de las publicaciones anteriores de Sangría, esta es la primera novela que no es una reedición de clásicos de la literatura chilena. Inaugurar, porque es una apuesta a una escritura que se desplaza de los parámetros del "mercado". Editar Los perplejos, en este sentido, es instalarse en la escena editorial nacional con cierta propiedad, con un material literario duro y de peso. Demás está decir -siguiendo la trayectoria escritural de Rimsky (La novela de otro, 2004, y Poste restante, 2001)- que su texto se escurre también de lo que se ha entendido por literaturas del margen, escritura femenina o de la subalternidad, aunque podría insertarse fácilmente en esas categorías y ser terreno para estudios académicos donde lo que prima, por lo general, es ajustar el texto a la teoría y no a la inversa.

Hace poco llegó a mis manos un capítulo del libro Kafka, por una literatura menor de Gilles Deleuze y Félix Guattari y mientras leía me resonaba constantemente la escritura de Rimsky, la teoría iluminaba un texto, en este caso, se hacía carne en un cuerpo literario. La escritura desplazada, desterritorializada, que se juega en el lenguaje y en el valor de la palabra, en su interpretación, en su revés. Los perplejos, que toma su nombre de la Guía de perplejos de Moshe Ben Maimon, se constituye en una manera de transitar y ser transitado por el mundo y, sobre todo, en una reflexión acerca de la interpretación y producción como un acto ideológico y estéticamente determinado. La novela, estructurada en cinco partes, acoge a dos narradores situados en tiempos y espacios distintos, cuyas voces terminan por fusionarse, puesto que, a pesar de la distancia espaciotemporal, se enfrentan a una misma incerteza, duda y reflexión que termina
\end{abstract}


por instalarse, a modo de proyección, en el lector: la exégesis literaria como ejercicio en que el signo se constituye en un terreno disputado. "Leer y comprender el reverso de las palabras" dice Moshe, respecto al libro de Job; leer y comprender la omisión, aquello que no siendo parte de una elección lingüístico literaria, se hace presente en los intersticios del juego verbal a pesar del autor -entendido como estrategia textual-. La tradición, la ley y el canon -en tanto parámetros ideológicos de un período determinado- son, en este sentido, conceptos cuestionados desde la subjetividad narrativa de las voces de la novela y ese cuestionamiento surge de problemáticas individuales: Moshe se propone descifrar el sentido profundo del libro de Job en diálogo con la mirada científica aristotélica en el siglo XII, mientras la escritora-que reconstruye la vida y el tránsito del filósofo judío medieval- intenta escribir una novela para cumplir un contrato contraído con el Consejo del Libro en el presente siglo. Ambos ejercicios se realizan en un contexto de extranjería, errancia, incertidumbre y, en el caso de Moshe, de persecución.

La literatura, la palabra y la escritura en ambos casos se erige en un espacio resistencial, entendido desde el lenguaje, como una manera de instalar, en los términos de Deleuze y Guattari, "los medios de otra conciencia y de otra sensibilidad". Parafraseando a Rimsky, lo que se cuela en la vida cotidiana es la incertidumbre y, la única salida, es una escritura que haga frente a la desarticulación del lenguaje en tanto certeza de ser: Moshe renuncia a su pretensión de convertirse en un gran maestro y traductor del Libro, para escribir una Guía que conduzca a los perplejos, un Compendio de la ley, mientras que la autora ya no distingue su propia voz de la voz de los otros: "Cuando un año más tarde decidí cambiar las citas, las palabras se habían adosado a las situaciones y no supe cómo desprenderlas". No existe voluntad autoral romántica, sólo la necesidad de escribir reconociendo las escrituras que han estado antes o que estarán en el futuro.

La escritura de Rimsky, tal como el proyecto de la autora de la novela y la exégesis de Moshe, está fuertemente atravesada por otras voces literarias, filosóficas, teóricas e históricas, con las que dialoga y establece relaciones, lo que se explicita como una suerte de poética en la propia novela como reflexión metaliteraria. La palabra que otros escribieron está presente de manera ineludible y crítica en lo que se escribe. El estatuto de lo literario, entonces, pasaría por la reescritura, la traducción y la interpretación de lo ya escrito. La lectura de Los perplejos, en este sentido, se enfrenta -con plena autonomía- a otros textos, lo que constituye uno de los ejes del placer estético y el carácter político de la novela de Rimsky. Roland Barthes, Susan Sontag con su clásico "Contra la interpretación”, Umberto Eco y su novela, 
que es al mismo tiempo un tratado semiótico, El nombre de la rosa o El lector in fábula, son los que se me vienen a la mente en este minuto desde un punto de vista teórico, y el sinfín de textos literarios que han abordado el viaje, partiendo por Joseph Conrad, que es mencionado explícitamente como fuente de escritura, para dar forma a una tormenta que acaece en una travesía en barco.

La lengua de Rimsky, tal como la de sus personajes/narradores de esta novela, tiene el signo de la desterritorialización, lo que se traduce a nivel anecdótico en sus travesías: Córdoba, Fez, Eslovenia, Alejandría, Santiago, Málaga, Medio Oriente y muchos otros espacios acogen la lengua errante -y la cultura inscrita en ella- de Moshe y la escritora. Uno huyendo de la persecución almorávide en el siglo XII, la otra siguiendo sus pasos hasta que se convence de que la historia sólo es una fábula, no en términos referenciales o de la existencia del personaje, sino porque el relato siempre es ficcional y está atravesado, precisamente, por una subjetividad que instala una forma de leer e interpretar los hechos, que corresponde a los paradigmas ideológicos imperantes en cada época. Es en la lengua, es decir, en la escritura donde los personajes encuentran su arraigo, su "patria", su lugar en el mundo. Pero como ya se dijo, el espacio del signo es el terreno de la disputa, por lo tanto se encontrarán siempre en un lugar sitiado, acosado por una lengua mayor. El viaje, en este caso y a diferencia de las otras novelas de Rimsky, es casi una excusa para explicitar la manera en que circula la palabra, la literatura y el sentido. Es el paso fronterizo, que demarca espacialmente la escritura, es un ir más allá de los caminos trazados: "Por primera vez enseño el camino que he borroneado todos estos años de exilio [...] Ahora que otros ojos me acompañan en mi recorrido reparo en las palabras mal colocadas", dice Moshe respecto de su propia escritura centrada en la interpretación profunda del texto de Job. La escritura como camino que se traza, como proyecto constructivo cuyos materiales son de diverso origen, que se detiene incluso en el proceso de restauración de un libro, que no sólo restaura su materialidad sino también su sentido, su lengua, su palabra. "Durante meses el único sonido que sale de la habitación es el de la aguja al entrar en el papel", tal como la traducción se introduce en la carne de un texto, para revelar lo omitido, lo soterrado, aquello que esconde. La traducción y la interpretación, en este sentido, es un acto de traición, pero al mismo tiempo restauratario, puesto que "el conocimiento profundo siembra la duda mientras la literalidad conserva intacta la fe [...] El sudor dejó las palabras en mi piel y la página en blanco".

Las voces narrativas de Los perplejos, claramente definidas a lo largo de 
toda la novela, sufren las mismas transformaciones, desde la certeza hacia la incertidumbre, de la voluntad escritural que comporta la decisión del viaje -uno voluntario y el otro obligado- hasta la disolución del relato en una misma voz en la que se sigue distinguiendo su individualidad. La escritura de uno contiene a la del otro. El yo que enuncia se espejea en el otro: una judía, con formación poco ortodoxa, que intenta escribir de aquel que hizo el Compendio de la ley, un filósofo judío que escribe para que todos accedan al conocimiento racional de Dios. Finalmente, ambos narradorespersonajes se erigen en una suerte de copistas que al margen de la página van iluminando los textos, espacio en que se juega su particular manera de leer e interpretar los textos.

La novela de Cynthia Rimsky nos sitúa en los proyectos de escritura y en los procesos de interpretación. Cómo se lee, qué se lee y su contraparte, cómo se escribe y qué se escribe, no en términos de una fórmula que se pueda seguir, sino en términos de la significación de dicho acto, qué es lo que se juega en dichos ejercicios. El viaje que propone Los perplejos es, en este sentido, hacia aquello que se lee entre líneas, donde el lector también es responsable de la producción de sentido. Es una invitación abierta. 